\title{
CIN85 defect in brain and neurobehavioral disorder: involvement in excess dopamine signaling
}

\author{
Noriaki Shimokawa*, Shinnosuke Masuda, Hiroko Masuda and Noriyuki Koibuchi \\ *Correspondence: simokawa@med.gunma-u.ac.jp \\ Department of Integrative Physiology, Gunma University Graduate School of Medicine, Gunma 371-8511, Japan.
}

\begin{abstract}
The Cbl-interacting protein of $85 \mathrm{kDa}$ (CIN85) belongs to a family of ubiquitously expressed adaptor/scaffold proteins. CIN85 interacts with endocytic proteins involved in various receptor signaling pathways. Despite extensive investigations of CIN85 in receptor trafficking, little is known about its functions in vivo. Mice deficient in brain-specific CIN85 expression show hyperactive phenotypes, which in many ways resemble the behavioural aberrations displayed in human beings affected by attention deficit/hyperactivity disorder (ADHD), a disorder strongly associated with abnormal dopamine signaling. ADHD is a neurobehavioural disorder characterized by either significant difficulties of inattention or hyperactivity and impulsiveness or a combination of the two. While genetic factors are strongly implicated in the etiology of ADHD, the genes responsible for ADHD are unknown. Here, we review the recent progress of CIN85 study and the possibility of ADHD onset owing to CIN85 defect in the brain.
\end{abstract}

Keywords: CIN85, dopamine signaling, CIN85 deficient mouse, attention deficit/hyperactivity disorder

\section{Introduction}

Adaptor proteins are noncatalytic polypeptides that contain one or more domains that are capable of binding to other proteins or nonprotein ligands [1]. These molecules are essential for intracellular signal transduction involved in the regulation of endocrine action, metabolic activity, neuronal function, and cell growth. Recently, there has been growing evidence that adaptor proteins play critical roles in neurobehavioral control. Glutamate receptor interacting protein 1 (GRIP1) regulates social behavior and modulates the autistic phenotype [2]. Maiya et al., reported [3] that a Lin11, IsI-1, and Mec-3(LIM) adaptor protein, LIM domain only protein 4 (LMO4), regulates fear learning. The G protein-coupled receptor kinase-interacting protein-1(GIT1) deficiency in mice causes psychostimulant-responsive attention deficit/hyperactivity disorder (ADHD)-like phenotypes [4].

The $\mathrm{Cbl}$-interacting protein of $85 \mathrm{kDa}$ (CIN85) is a multiadaptor protein containing three $\mathrm{Srchomology}(\mathrm{SH}) 3$ domains, a prolinerich region and a coiled-coil domain [5]. CIN85 was shown to link Cbl-epidermal growth factor receptor (EGFR) complexes with endophilin-dependent receptor internalization [6]. Recently, we have reported a novel in vivo function of CIN85 in the regulation of postsynaptic dopamine receptor endocytosis in striatal neurons [7]. Mice deficient in CIN85 (CIN85 ${ }^{\text {ex22}}$, lacking CIN85 exon 2) expression show ADHD phenotypes. As a molecular explanation of this phenotype, we concluded that the absence of striatal CIN85 causes insufficient complex formation of endophilins with dopamine receptors in the striatum and ultimately decreased dopamine receptor endocytosis in striatal neurons in response to dopamine stimulation.

ADHD is one of the most common childhood disorders and can continue through adolescence and adulthood. Symptoms include difficulty staying focused and paying attention, difficulty controlling behavior, and hyperactivity [8]. It has not been clear until now what causes ADHD. Various factors have been suggested, and genes are believed to play a critical role in ADHD onset [9].

In the present review, we briefly describe a novel function of the adaptor/scaffold protein CIN85 in the regulation of neurobehavior and the possibility of ADHD onset owing to CIN85 defect in the brain.

\section{Structure and function of CIN85}

CIN85 was independently identified as CIN85 [5], regulator of ubiquitous kinase (Ruk) [10], SH3-domain-containing gene expressed in tumorigenic astrocytes (SETA) [11] and $\mathrm{SH} 3$ domain kinase binding protein 1 (SH3KBP1) [12]. These genes were isolated from either human (CIN85), rat (Ruk and SETA) or mouse (SH3KBP1) sources and show between $92 \%$ and $97 \%$ sequence identities, suggesting that they represent homologues of one gene. The CIN85 gene is localized on the short arm of the $X$ chromosome (Xp22.1-p21.3) and its length is approximately $353.7 \mathrm{~kb}$ in humans (http://www.ncbi.nlm.nih.gov/sites/entrez?db=g ene\&cmd=retrieve\&dopt=full_report\&list_uids $=30011$ ). The main 3.2 $\mathrm{kb}$ CIN85 mRNA is expressed in all adult and newborn tissues $[5,10]$. Owing to alternative splicing and the use of different promoters, multiple CIN85 mRNA signals have been detected, which showed a more restricted pattern of expression [10]. CIN85 is composed of three $\mathrm{N}$-terminal SH3 domains, followed by a centrally located proline-rich region and a C-terminal coiled coil domain [13]. Initially, CIN85 was identified as a negative regulator of EGFR signaling and phosphoinositide 3-kinase (PI 3-kinase) signaling pathways via its interaction 


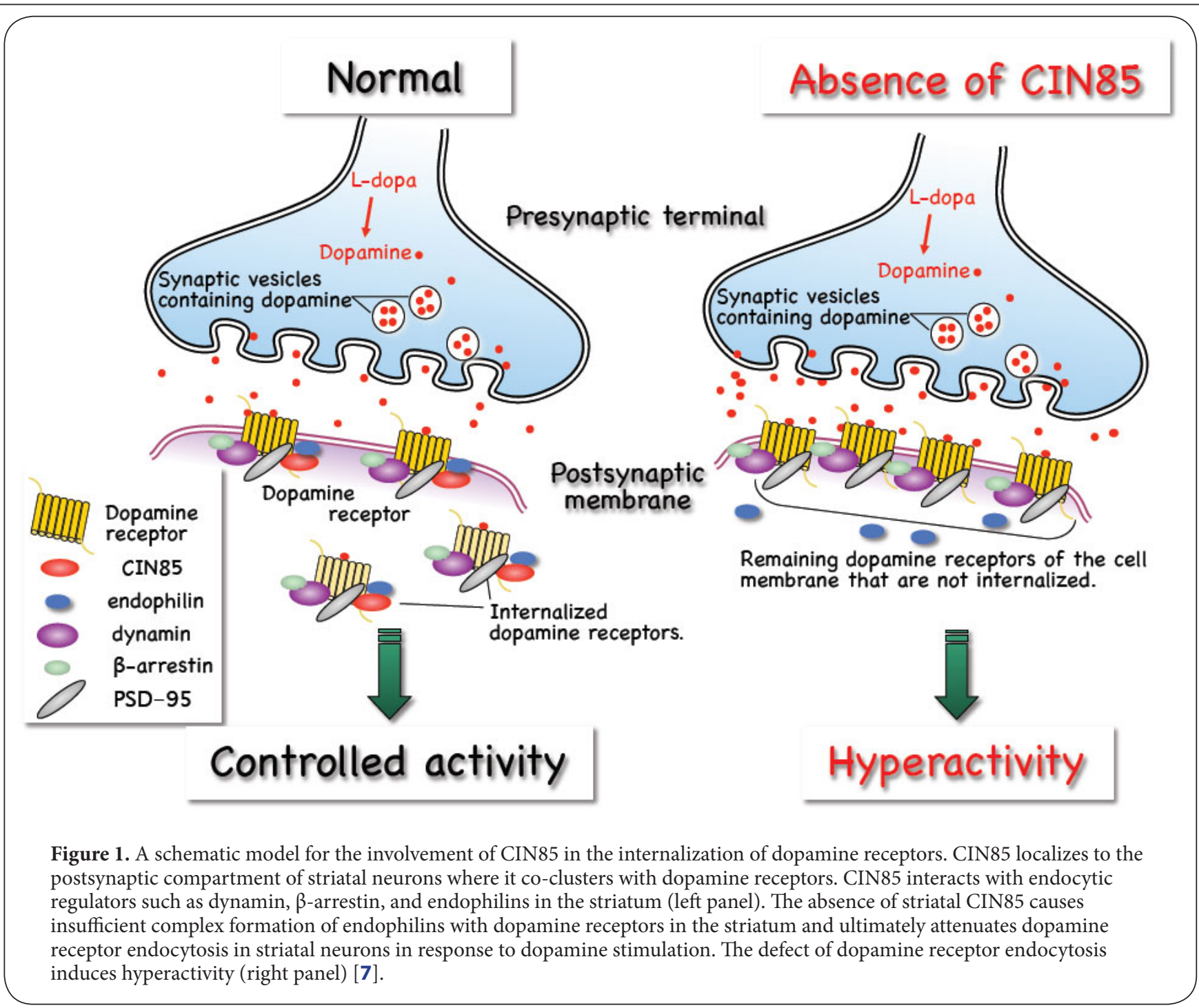

with c-Cbl $[5,10]$. Then, CIN85 was identified as a central adaptor molecule involved in the recruitment of the endocytic machinery required for the internalization of various cell surface receptors, including receptor tyrosine kinases such as EGFR $[6,14]$, hepatocyte growth factor receptor (HGFR, Met) [15], and vascular endothelial growth factor receptor (VEGFR) [16], and also immunoglobulin IgE receptors in mast cells [17]. Recently, it has been reported that CIN85 is involved in the regulation of the immune system and cytokinesis. Using $B$ cell-specific CIN85 knockout mice, Kometani et al., [18] found that CIN85 links the B cell receptor to IkB kinase- $\beta$ /nuclear factor-kappa $B($ IKK- $\beta / N F k B)$ activation, thereby contributing to $T$ cell-independent immune responses. Haglund et al., [19] reported that Cindr, a Drosophila CD2AP/CIN85 ortholog, interacts with Anillin and that depletion of either Cindr or Anillin gives rise to binucleate cells and fewer intercellular bridges in vivo; therefore, Cindr is involved in complete and incomplete cytokineses in Drosophila. In the future, on the basis of these reports, a novel function of CIN85 may be identified since CIN85 is expressed ubiquitously.

\section{Hyperactivity phenotypes of CIN85-deficient mice} Recently, we have found a novel function of CIN85 in the regulation of the signaling associated with behavior [7]. In the mouse brain, the two major isoforms expressed, CIN85$\mathrm{XI}$ and CIN85-I, were found to be abundant in most brain regions examined $[\mathbf{7 , 2 0 ]}$. Interestingly, CIN85-xl is expressed only in the central nervous system (CNS). Furthermore, CIN85 colocalizes with postsynaptic density protein 95 (PSD-95) at postsynaptic sites in the somatodendritic compartment in which it frequently clustered in dendritic shafts, as well as within dendritic spines [7]. Dendritic spines are small protrusions extending from the surface of dendrites, which are believed to be the main sites of excitatory synapses and are thus vital centers for synaptic transmission in the brain [21]. To investigate the function of CIN85 in the CNS, we generated 
mice deficient in the two major CIN85 isoforms expressed in the brain (CIN85-xl and CIN85-I) [7]. By homologous recombination, we deleted exon 2 of the CIN85 genomic locus (CIN85 $\left.{ }^{\Delta e x 2}\right)$. As expected, all CIN85 protein variants encoded by transcripts initiated from promoter \#1 (CIN85-Xl, CIN85-I, and the shorter CIN85- $\triangle C P$ ) were abolished in CIN85 ${ }^{\Delta \mathrm{ex} 2}$ mice.

CIN $85^{\Delta \times 2}$ mice are viable and fertile, and display no obvious abnormalities in appearance. We subjected the CIN85 ${ }^{\operatorname{\Delta x} 2}$ mice to extensive analyses of a broad range of parameters in accordance with the physiological screens defined by the German Mouse Clinic (http://www.mouseclinic.de/). Among the parameters tested, the mice showed a clear knockout-specific phenotype in behavior. When subjected to the modified holeboard test [22], which assays spontaneous behavior such as forward and vertical locomotor activity, speed of movement, and exploratory behavior in a novel environment, the CIN85 $5^{\Delta \times 2}$ mice showed significantly increased activities, as compared with the wildtype. Specifically, the CIN85 ${ }^{\Delta \times 2}$ mice exhibited increased forward locomotor activity, as manifested by increases in total distance travelled, number of line crossings, mean and maximum velocities, as well as turning frequency. In addition, $\mathrm{CIN} 85^{\Delta \mathrm{ex} 2}$ mice showed enhanced exploratory behavior, namely, entering the board more frequently and exploring a larger number of holes on the board than the wild-type mice.

Involvement of CIN85 in dopamine receptor endocytosis The genetics behind behavioral traits such as locomotor activity and exploratory ambition is undoubtedly highly complex and involves a multitude of pathways, among which dopaminergic, serotonergic and noradrenergic signaling pathways are frequently quoted [23]. On the basis of many studies on the involvement of dopaminergic signaling in the regulation of movement, learning, reward-seeking behavior and motivation [24], together with the rich clustering of dopamine receptors in dendritic spines [25-27], we investigated whether CIN85 could be involved in the regulation of such pathways.

Interestingly, the CIN85 $5^{\Delta e x 2}$ mice display abnormally high levels of dopamine and D2 dopamine receptors (D2DRs) in the striatum [7], an important center for the coordination of animal behavior. Importantly, CIN85 localizes to the postsynaptic compartment of striatal neurons, in which it co-clusters with D2DRs. Moreover, it interacts with endocytic regulators such as dynamin and endophilins in the striatum. In neurons of the wild-type mice, CIN85 resides postsynaptically and associates with endocytic regulators, such as dynamin and endophilins, and it clearly has a crucial function in stabilizing endophilin binding to D2DRs in the striatum. The internalization of D2DRs is caused by the coordination of these endocytic proteins. As a result, dopamine signals are attenuated, and then the appropriate locomotor activity is maintained (Figure 1, left panel). As a consequence, the absence of CIN85 gives rise to insufficient endocytic internalization of D2DRs owing to the lack of endophilin recruitment to the endocytic complex after dopamine stimulation, increasing striatal dopamine receptor levels, which can, at least in part, explain the enhanced locomotor and exploratory behavior we observe in the $\mathrm{CIN} 85^{\Delta \mathrm{ex} 2}$ mice (Figure 1, right panel). The resulting increase in the expression levels of surface-associated D2DRs in CIN85 $5^{\Delta e \times 2}$ mouse striatal neurons and the ensuing hyperactivity phenotype are in line with earlier findings, showing that activation of postsynaptic D2DRs results in increased locomotor activity and that D2DR knockout mice display reduced spontaneous movements $[\mathbf{2 8 , 2 9 ]}$.

\section{ADHD and genetic aspects}

ADHD is the most common behavioral disorder of childhood, affecting $8-12 \%$ of children around the world $[30,31]$. The disorder is defined as a persistent syndrome characterized by inattention, excessive motor activity, and impulsivity by The Diagnostic and Statistical Manual of Mental Disorders (DSM-IV-TR) published by the American Psychiatric Association. While the etiology of ADHD seems to be primarily a genetic factor, the disorder does not seem to be caused by a singlegene defect. Currently, as argued by many researchers, ADHD cases may arise from a combination of various genes, many of which affect neurotransmitter signaling, synthesis and modification. Candidate genes include D4 dopamine receptor (D4DR) [32-34], D5 dopamine receptor (D5DR) [35-37], dopamine transporter 1 (DAT1) [38,39], 5-hydroxy-tryptamine transporter (5-HTT, serotonin transporter) [34,40,41], arrestin $\beta-2$ [39], phenylethanolamine $\mathrm{N}$-methyltransferase (PNMT) [39] and monoamine-oxidase A (MAOA) [42]. More recently, Arcos-Burgos et al., [43] have reported that a linkage study using worldwide samples (total $n=6360$, with 2627 ADHD cases and 2531 controls) discovered a genome region in the latrophilin 3 gene (LPHN3), and the statistical association of LPHN3 and ADHD was confirmed.

Currently, there is no information on whether ADHD patients have the mutation/deletion of the CIN85 gene. However, as mentioned earlier, the loss-of-function of CIN85 in the brain causes hyperactivity in mice through the defect of dopamine receptor endocytosis. The molecular defects underlying the onset of ADHD have not been fully characterized, but may include alterations in the expression levels of dopamine ligands and receptors, as well as defects in downstream signaling events $[\mathbf{4 4 , 4 5 ]}$.

CIN85 is a novel regulator of dopamine receptor endocytosis, involved in controlling behavior, and the use of $\mathrm{CIN} 85^{\Delta \times 2}$ mice can lead to new developments in ADHD research.

\section{Abbreviations}

ADHD: attention deficit/hyperactivity disorder

CD2AP: CD2-associated protein

CIN85: Cbl-interacting protein of $85 \mathrm{kDa}$

CNS: central nervous system

DAT1: dopamine transporter 1

DR: dopamine receptor

EGFR: epidermal growth factor receptor 
Shimokawa et al. Hormonal Studies 2013,

GIT1: G protein-coupled receptor kinase-interacting protein-1 GRIP1: glutamate receptor interacting protein 1

HGFR: hepatocyte growth factor receptor

5-HTT: 5-hydroxy-tryptamine transporter

IKK- $\beta / N F k B$ : IkB kinase- $\beta /$ nuclear factor-kappa B

LIM: Lin 11, Isl-1 and Mec-3

LMO4: LIM domain only protein 4

LPHN3: latrophilin 3

MAOA: monoamine-oxidase A

PI 3-kinase: phosphoinositide 3-kinase

PNMT: phenylethanolamine $\mathrm{N}$-methyltransferase

PSD-95: postsynaptic density protein 95

Ruk: regulator of ubiquitous kinase

SETA: SH3 domain-containing gene expressed in tumorigenic astrocytes

SH3: Src homology 3

SH3KBP1: SH3 domain kinase binding protein 1

VEGFR: vascular endothelial growth factor receptor

\section{Competing interests}

The authors declare that they have no competing interests.

\section{Authors' contributions and disclosures}

All theauthors contributed to the design and conduct of the study, collection, analysis, and interpretation of data, and manuscript writing, and have no conflicts of interest.

\section{Acknowledgement}

This work was supported by a Grant-in-Aid for Scientific Research on Priority Areas (18059005), (20056004) and by a Grant-in-Aid for Scientific Research on Innovative Areas (Brain Environment; 24111506) from MEXT of Japan to NS.

\section{Publication history}

Editor: Pablo J Enriori, Monash University, Australia.

EIC: Masayoshi Yamaguchi, Emory University School of Medicine, USA. Received: 23-May-2013 Revised: 22-Aug-2013

Accepted: 28-Aug-2013 Published: 11-Sep-2013

\section{References}

1. Pawson $T$, Raina $M$ and Nash P. Interaction domains: from simple binding events to complex cellular behavior. FEBS Lett. 2002; 513:2-10 | Article | PubMed

2. Mejias R, Adamczyk A, Anggono V, Niranjan T, Thomas GM, Sharma K, Skinner C, Schwartz CE, Stevenson RE, Fallin MD et al. Gain-of-function glutamate receptor interacting protein 1 variants alter GluA2 recycling and surface distribution in patients with autism. Proc Natl Acad Sci U S A. 2011; 108:4920-5. | Article | PubMed Abstract | PubMed Full Text

3. Maiya R, Kharazia V, Lasek AW and Heberlein U. Lmo4 in the basolateral complex of the amygdala modulates fear learning. PLoS One. 2012; 7:e34559. | Article | PubMed

4. Won H, Mah W, Kim E, Kim JW, Hahm EK, et al. GIT1 is associated with ADHD in humans and ADHD-like behaviors in mice. Nat Med. 2011; 17:566-72. | Article | PubMed

5. Take H, Watanabe S, Takeda K, Yu ZX, Iwata N and Kajigaya S. Cloning and characterization of a novel adaptor protein, CIN85, that interacts with c-Cbl. Biochem Biophys Res Commun. 2000; 268:321-8. | Article | PubMed

6. Soubeyran P, Kowanetz K, Szymkiewicz I, Langdon WY and Dikic I. CblCIN85-endophilin complex mediates ligand-induced downregulation of EGF receptors. Nature. 2002; 416:183-7. I Article I PubMed

7. Shimokawa N, Haglund K, Holter SM, Grabbe C, Kirkin V, Koibuchi N, Schultz C, Rozman J, Hoeller D, Qiu CH et al. CIN85 regulates dopamine receptor endocytosis and governs behaviour in mice. EMBO J. 2010; 29:2421-32. | Article | PubMed Abstract | PubMed Full Text

8. Biederman J and Faraone SV. Attention-deficit hyperactivity disorder.
Lancet. 2005; 366:237-48. | Article I PubMed

9. Gizer IR, Ficks C and Waldman ID. Candidate gene studies of ADHD: a meta-analytic review. Hum Genet. 2009; 126:51-90. | Article I PubMed

10. Gout I, Middleton G, Adu J, Ninkina NN, Drobot LB, Filonenko V, Matsuka G, Davies AM, Waterfield M and Buchman VL. Negative regulation of PI 3-kinase by Ruk, a novel adaptor protein. EMBO J. 2000; 19:4015-25. I Article | PubMed Abstract | PubMed Full Text

11. Borinstein SC, Hyatt MA, Sykes VW, Straub RE, Lipkowitz S, Boulter J and Bogler O. SETA is a multifunctional adapter protein with three SH3 domains that binds $\mathrm{Grb2}, \mathrm{Cbl}$, and the novel SB1 proteins. Cell Signal. 2000; 12:769-79. I Article I PubMed

12. Narita T, Amano F, Yoshizaki K, Nishimoto N, Nishimura T, Tajima T, Namiki $\mathrm{H}$ and Taniyama T. Assignment of SH3KBP1 to human chromosome band Xp22.1-->p21.3 by in situ hybridization. Cytogenet Cell Genet. 2001; 93:133-4. I Article I PubMed

13. Dikic I. CIN85/CMS family of adaptor molecules. FEBS Lett. 2002; 529:110-5. | Article | PubMed

14. Haglund K, Shimokawa N, Szymkiewicz I and Dikic I. Cbl-directed monoubiquitination of CIN85 is involved in regulation of ligand-induced degradation of EGF receptors. Proc Natl Acad Sci U S A. 2002; 99:121916. | Article | PubMed Abstract | PubMed Full Text

15. Petrelli A, Gilestro GF, Lanzardo S, Comoglio PM, Migone N and Giordano $\mathrm{S}$. The endophilin-CIN85-Cbl complex mediates ligand-dependent downregulation of c-Met. Nature. 2002; 416:187-90. | Article | PubMed

16. Kobayashi S, Sawano A, Nojima Y, Shibuya M and Maru Y. The c-Cbl/ CD2AP complex regulates VEGF-induced endocytosis and degradation of Flt-1 (VEGFR-1). FASEB J. 2004; 18:929-31. | Article I PubMed

17. Molfetta R, Belleudi F, Peruzzi G, Morrone S, Leone L, Dikic I, Piccoli M, Frati L, Torrisi MR, Santoni A and Paolini R. CIN85 regulates the ligand-dependent endocytosis of the IgE receptor: a new molecular mechanism to dampen mast cell function. J Immunol. 2005; 175:420816. I Article I PubMed

18. Kometani K, Yamada T, Sasaki Y, Yokosuka T, Saito T, Rajewsky K, Ishiai $M$, Hikida $M$ and Kurosaki T. CIN85 drives B cell responses by linking BCR signals to the canonical NF-kappaB pathway. J Exp Med. 2011; 208:1447-57. | Article | PubMed Abstract | PubMed Full Text

19. Haglund K, Nezis IP, Lemus D, Grabbe C, Wesche J, Liestol K, Dikic I, Palmer R and Stenmark H. Cindr interacts with anillin to control cytokinesis in Drosophila melanogaster. Curr Biol. 2010; 20:944-50. I Article | PubMed

20. Buchman VL, Luke C, Borthwick EB, Gout I and Ninkina N. Organization of the mouse Ruk locus and expression of isoforms in mouse tissues. Gene. 2002; 295:13-17. | Article | PubMed

21. Segal M. Dendritic spines and long-term plasticity. Nat Rev Neurosci. 2005; 6:277-84. | Article | PubMed

22. Ohl F, Holsboer F and Landgraf R. The modified hole board as a differential screen for behavior in rodents. Behav Res Methods Instrum Comput. 2001; 33:392-7. | PubMed

23. Pattij T and Vanderschuren LJ. The neuropharmacology of impulsive behaviour. Trends Pharmacol Sci. 2008; 29:192-9. | Article | PubMed

24. Yao WD, Spealman RD and Zhang J. Dopaminergic signaling in dendritic spines. Biochem Pharmacol. 2008; 75:2055-69. | Article I PubMed Abstract | PubMed Full Text

25. Gainetdinov RR, Premont RT, Bohn LM, Lefkowitz RJ and Caron MG. Desensitization of $\mathrm{G}$ protein-coupled receptors and neuronal functions. Annu Rev Neurosci. 2004; 27:107-44. I Article I PubMed

26. Viggiano D, Vallone D and Sadile A. Dysfunctions in dopamine systems and ADHD: evidence from animals and modeling. Neural Plast. 2004; 11:97-114. | Article | PubMed Abstract | PubMed Full Text

27. Zhu G, Okada M, Yoshida S, Hirose S and Kaneko S. Both 3,4-dihydroxyphenylalanine and dopamine releases are regulated by Ca2+-induced Ca2+ releasing system in rat striatum. Neurosci Lett. 2004; 362:244-8. | Article | PubMed

28. Jackson DM and Westlind-Danielsson A. Dopamine receptors: molecular biology, biochemistry and behavioural aspects. Pharmacol Ther. 1994; 64:291-370. | Article | PubMed 
Shimokawa et al. Hormonal Studies 2013,

29. Baik JH, Picetti R, Saiardi A, Thiriet G, Dierich A, Depaulis A, Le Meur M and Borrelli E. Parkinsonian-like locomotor impairment in mice lacking dopamine D2 receptors. Nature. 1995; 377:424-8. | Article | PubMed

30. Spencer TJ, Biederman J and Mick E. Attention-deficit/hyperactivity disorder: diagnosis, lifespan, comorbidities, and neurobiology. J Pediatr Psychol. 2007; 32:631-42. | Article | PubMed

31. Arcos-Burgos $M$ and Acosta MT. Tuning major gene variants conditioning human behavior: the anachronism of ADHD. Curr Opin Genet Dev. 2007; 17:234-8. | Article | PubMed

32. Faraone SV, Biederman J, Weiffenbach B, Keith T, Chu MP, Weaver A Spencer TJ, Wilens TE, Frazier J, Cleves M and Sakai J. Dopamine D4 gene 7-repeat allele and attention deficit hyperactivity disorder. Am J Psychiatry. 1999; 156:768-70. | Article | PubMed

33. Faraone SV, Doyle AE, Mick E and Biederman J. Meta-analysis of the association between the 7-repeat allele of the dopamine $D(4)$ receptor gene and attention deficit hyperactivity disorder. Am J Psychiatry. 2001; 158:1052-7. | Article | PubMed

34. Thapar A, O'Donovan M and Owen MJ. The genetics of attention deficit hyperactivity disorder. Hum Mol Genet. 2005; 14 Spec No. 2:R275-82. | Article I PubMed

35. Li D, Sham PC, Owen MJ and He L. Meta-analysis shows significant association between dopamine system genes and attention deficit hyperactivity disorder (ADHD). Hum Mol Genet. 2006; 15:2276-84. | Article I PubMed

36. Maher BS, Marazita ML, Ferrell RE and Vanyukov MM. Dopamine system genes and attention deficit hyperactivity disorder: a meta-analysis. Psychiatr Genet. 2002; 12:207-15. I Article I PubMed

37. Lowe N, Kirley A, Hawi Z, Sham P, Wickham H, Kratochvil CJ, Smith SD, Lee SY, Levy F, Kent L et al. Joint analysis of the DRD5 marker concludes association with attention-deficit/hyperactivity disorder confined to the predominantly inattentive and combined subtypes. Am J Hum Genet. 2004; 74:348-56. | Article | PubMed Abstract | PubMed Full Text

38. Friedel S, Saar K, Sauer S, Dempfle A, Walitza S, Renner T, Romanos M Freitag C, Seitz C, Palmason $\mathrm{H}$ et al. Association and linkage of allelic variants of the dopamine transporter gene in ADHD. Mol Psychiatry. 2007; 12:923-33. | Article I PubMed

39. Brookes K, Xu X, Chen W, Zhou K, Neale B, Lowe N, Anney R, Franke B, Gill M, Ebstein $\mathrm{R}$ et al. The analysis of $\mathbf{5 1}$ genes in DSM-IV combined type attention deficit hyperactivity disorder: association signals in DRD4, DAT1 and 16 other genes. Mol Psychiatry. 2006; 11:934-53. Article | PubMed

40. Banerjee E, Sinha S, Chatterjee A, Gangopadhyay PK, Singh M and Nandagopal K. A family-based study of Indian subjects from Kolkata reveals allelic association of the serotonin transporter intron-2 (STin2) polymorphism and attention-deficit-hyperactivity disorder (ADHD). Am J Med Genet B Neuropsychiatr Genet. 2006; 141B:361-6. | Article | PubMed

41. Kent L, Green E, Hawi Z, Kirley A, Dudbridge F, Lowe N, Raybould R, Langley K, Bray N, Fitzgerald M et al. Association of the paternally transmitted copy of common Valine allele of the Val66Met polymorphism of the brain-derived neurotrophic factor (BDNF) gene with susceptibility to ADHD. Mol Psychiatry. 2005; 10:939-43. | Article I PubMed

42. Manor I, Tyano S, Mel E, Eisenberg J, Bachner-Melman R, Kotler M and Ebstein RP. Family-based and association studies of monoamine oxidase A and attention deficit hyperactivity disorder (ADHD): preferential transmission of the long promoter-region repeat and its association with impaired performance on a continuous performance test (TOVA). Mol Psychiatry. 2002; 7:626-32. | Article | PubMed

43. Arcos-Burgos M, Jain M, Acosta MT, Shively S, Stanescu H, Wallis D, Domene S, Velez JI, Karkera JD, Balog J et al. A common variant of the latrophilin 3 gene, LPHN3, confers susceptibility to ADHD and predicts effectiveness of stimulant medication. Mol Psychiatry. 2010; 15:105366. | Article | PubMed

44. Bellgrove MA and Mattingley JB. Molecular genetics of attention. Ann N Y Acad Sci. 2008; 1129:200-12. | Article | PubMed

45. O'Connell RG, Bellgrove MA, Dockree PM, Lau A, Fitzgerald M and
Robertson IH. Self-Alert Training: volitional modulation of autonomic arousal improves sustained attention. Neuropsychologia. 2008; 46:1379-90. | Article | PubMed 